\title{
Correction to: Development of Strategies to Reduce Ventilation and Heating Costs in a Swedish Sublevel Caving Mine-a Unique Case of LKAB's Konsuln Mine
}

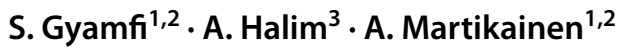 \\ Published online: 23 December 2021 \\ (c) Society for Mining, Metallurgy \& Exploration Inc. 2021
}

\section{Correction to: Mining, Metallurgy \& Exploration https://doi.org/10.1007/s42461-021-00483-y}

The authors apologize for some omissions in the original article:

\begin{abstract}
Section $2-$ Konsuln Mine Ventilation System, $2^{\text {nd }}$ paragraph.

Add "The design was created by Kiruna mine ventilation team, Ms. Stina Klemo and Mr. Joakim Jonasson, in cooperation with a consultant, Mr. Tomas Bolsöy from EOL Vent Mining AB" after "The system is designed to supply approximately $100 \mathrm{~m} 3 / \mathrm{s}$ of fresh air into the mine for a production rate of $0.8 \mathrm{Mtpa}$.
\end{abstract}

\section{Section 4.2 - Estimation of Ventilation Power Cost Using} VentSim Design Software, $1^{\text {st }}$ paragraph.

Add ",based on the model created by Mr. Tomas Bolsöy from EOL Vent Mining AB" after "The model was calibrated beforehand, as described in [26]".

Acknowledgements Add "and providing information regarding the original design of Konsuln mine ventilation and heating system" after "for her assistance in data collection for this study"

Publisher's Note Springer Nature remains neutral with regard to jurisdictional claims in published maps and institutional affiliations.

The original article can be found online at https://doi. org/10.1007/s42461-021-00483-y.

A. Halim

adrianus.halim@1tu.se

1 Luossavaara-Kiirunavaara Aktiebolag (LKAB), Kiruna, Sweden

2 Luossavaara-Kiirunavaara Aktiebolag (LKAB), Malmberget, Sweden

3 Luleå University of Technology, Luleå, Sweden 